Research Article

\title{
Patterns of genetic diversity in southern and southeastern Araucaria angustifolia (Bert.) O. Kuntze relict populations
}

Maria Isabel Ferreira de Souza ${ }^{1}$, Fabiano Salgueiro ${ }^{2}$, Mariana Carnavale-Bottino ${ }^{1}$, Durvalina Benedita Félix ${ }^{1}$, Marcio Alves-Ferreira ${ }^{1}$, Juliana Vitoria Messias Bittencourt ${ }^{3}$ and Rogério Margis ${ }^{4,5}$

${ }^{1}$ Laboratório de Genética Molecular Vegetal, Departamento de Genética, Instituto de Biologia, Universidade Federal do Rio de Janeiro, Rio de Janeiro, RJ, Brazil.

${ }^{2}$ Departamento de Genética, Instituto de Biologia, Universidade Federal Rural do Rio de Janeiro, Rio de Janeiro, RJ, Brazil.

${ }^{3}$ Universidade Tecnológica Federal do Paraná, Campus Dois Vizinhos, Paraná, PR, Brazil.

${ }^{4}$ Laboratório de Genomas e Populações de Plantas, Centro de Biotecnologia, Universidade Federal do Rio Grande do Sul, Porto Alegre, RS, Brazil.

${ }^{5}$ Departamento de Bioquímica, Universidade Federal do Rio Grande do Sul, Porto Alegre, RS, Brazil.

\begin{abstract}
Habitat fragmentation and a decrease in population size may lead to a loss in population genetic diversity. For the first time, the reduction in genetic diversity in the northernmost limit of natural occurence (southeastern Brazil) of Araucaria angustifolia in comparison with populations in the main area of the species continuous natural distribution (southern Brazil), was tested. The 673 AFLPs markers revealed a high level of genetic diversity for the species $(H t=0.27)$, despite anthropogenic influence throughout the last century, and a decrease of $H$ in isolated populations of southeastern Brazil $(H=0.16)$, thereby indicating the tendency for higher genetic diversity in remnant populations of continuous forests in southern Brazil, when compared to natural isolated populations in the southeastern region. A strong differentiation among southern and southeastern populations was detected (AMOVA variance ranged from $10 \%-15 \%)$. From Bayesian analysis, it is suggested that the nine populations tested form five "genetic clusters" $(K=5)$. Five of these populations, located in the northernmost limit of distribution of the species, represent three "genetic clusters". These results are in agreement with the pattern of geographic distribution of the studied populations.
\end{abstract}

Key words: Araucariaceae, relict populations, araucaria forest, population genetics, AFLP.

Received: October 22, 2008; Accepted: March 23, 2009.

\section{Introduction}

Deforestation is one of the main factors leading to forest fragmentation, or in other words, the complete transformation of a large area from a continuum of habitats to a large number of small patches of vegetation isolated one from the other (Macedo, 1993; Young et al., 1996). Habitat fragmentation may lead to a loss in population genetic diversity through different processes. In the first instance, a drastic reduction in population size can result in the loss of small frequency alleles. This usually occurs since part of the remanescent individuals may constitute an insignificant sample of the original genetic pool (Frankel and Soule, 1981). It is impossible to predict to what extent this may occur. Thus, it is extremely important to be well-aware of

Send correspondence to Fabiano Salgueiro. Departamento de Genética, Instituto de Biologia, Universidade Federal Rural do Rio de Janeiro, Rodovia BR 465 km 47, Sala 46, 23890-000 Seropédica, RJ, Brazil. E-mail: fabiano.salgueiro@gmail.com. both the levels of reduction in forest vegetation as well as the genetic structure of natural populations present during the fragmentation process. The immediate loss of heterozigosity will only be noticed in the event of the population suffering a large reduction in size (White et al., 1999).

The fragmentation of forests into small patches is responsible for the diminishing habitat-area (Watts et al., 2005), and for a reduction in the effective size of reproductive individuals, thereby increasing the probability of inbreeding among related trees. If this actually occurs, a consequential loss of genetic diversity is expected over long term, mainly due to stochastic events associated with inbreeding populations of diminished size and genetic drift (Menges, 1991; Ellstrand and Elam, 1993; Bouzat, 2001).

Araucaria angustifolia (Bertol.) Kuntze, also known as the Brazilian pine, is a dioecious wind-pollinated species whose seeds are dispersed mainly by authocory. A. angustifolia is one of the most important trees in its natural range of distribution, due to its economical, social and eco- 
logical relevance. As a result of the high quality of its timber, the wood is used for construction in general, furniture making and the production of long-fibre cellulose (Carvalho, 2003). Furthermore, through being rich in starch, the seeds constitute an important source of nutrients for humans (Reitz et al., 1988). Until now, araucaria buds are used in popular medicine (Marquesini, 1995). As to the species ecological relevance, it is known by its typical pioneer behavior (Reitz et al., 1988) and for being a sun-loving species during the very first stages of development (Rizzini, 1976). Hence, populations formed by adult individual araucaria make it possible for shade-tolerant plants of different taxa to grow and develop properly (Carvalho, 2003).

According to the records, the estimated natural area of distribution of $A$. angustifolia was formerly about 200,000 square kilometers (Reitz et al., 1988). However, at the beginning of the last century, the species underwent indiscriminate exploitation, mainly as a result of its social and economic relevance (Guerra et al., 2002), thus occasioning a severe reduction of this natural area. It is estimated that, at present, only about 1 to $5 \%$ of the former A. angustifolia natural range still remains, thus placing the species in the critically endangered category (Ibama, 1992; IUCN, 2008).

Nowadays, araucaria forests are restricted to altitudes above $600 \mathrm{~m}$, over a wide natural range in the three southernmost states of Brazil (Rio Grande do Sul, Santa Catarina and Paraná), between latitudes $24^{\circ}$ and $30^{\circ} \mathrm{S}$. The species is also sparsely spread throughout other states in Brazil, such as Minas Gerais, São Paulo and Rio de Janeiro, as isolated, relict populations, between latitudes 18 and $24^{\circ} \mathrm{S}$ and at higher altitudes $(1200 \mathrm{~m})$. It also occurs as a small extant population in the Province of Missiones, in Argentine (Hueck, 1972; Mattos, 1994) (Figure 1). However, in the past, the species was spread further north. Ruschi (1950) describes a no longer existent population of araucaria from the southern region of the state of Espírito Santo (Serra do Caparaó, Latitude $20^{\circ} 26^{\prime}$ S, $1700 \mathrm{~m}$ elevation). Based on palynological studies, Ledru et al. (1996) reported the presence of A. angustifolia pollen records from the Late Pleistocene in the "Lagoa Campestre" lake in Salitre, in the state of Minas Gerais ( $19^{\circ} \mathrm{S}, 46^{\circ} 46^{\prime} \mathrm{W}$, at $\left.970 \mathrm{~m}\right)$. Studies based on the "Bioclim" algorithm (Busby, 1991), as mentioned by Koch et al. (2007), and that take into account data on species occurrence, mean pluviometry and mean temperature, confirm that araucaria forests can occur at lower latitudes.

It is possible that the depletion of wide areas of araucaria forests may have led to a decrease in genetic diversity, to the point of interfering in its use for conservation and exploitation of its genetic resources. At present, a large number of approaches have been undertaken by using various markers, all of which point to the fact that, notwithstanding araucaria forests having undergone drastic reduction in areas of natural distribution, a considerable level of genetic diversity has still been maintained (Shimizu et al., 2000;

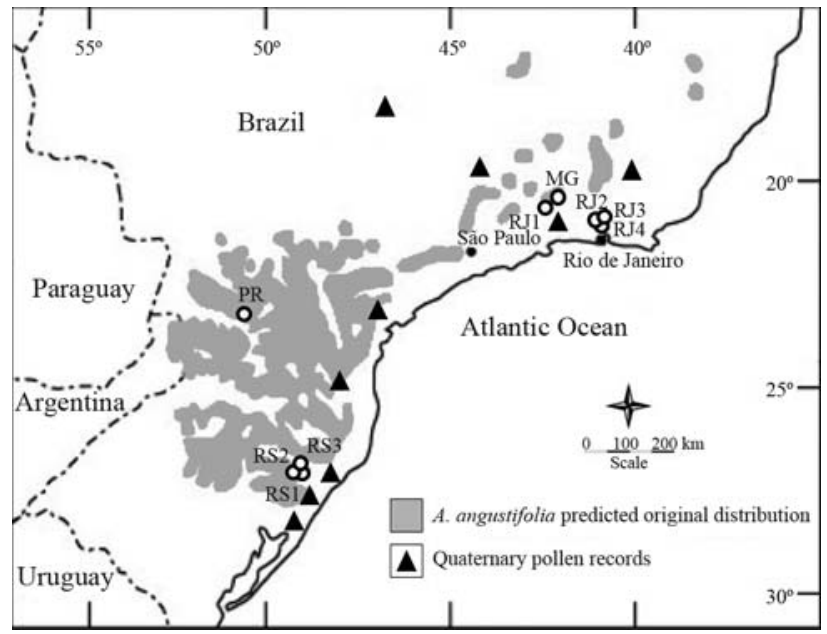

Figure 1 - Map showing the estimated original distribution of Araucaria angustifolia in Brazil, location of late Quaternary pollen records containing Araucaria (Kershaw and Wagstaff, 2001) and the sampled populations: RS-1, RS-2, RS-3, PR, MG, RJ-1, RJ-2, RJ-3 and RJ-4.

Medri et al., 2003; Mantovani et al., 2006, Stefenon et al., 2007). Nevertheless, most of the present studies have focused on remnant populations of continuous forests in southern Brazil. To date, there are no studies focusing on analyzing genetic diversity in natural, isolated and relict populations of $A$. angustifolia in southeastern Brazil. The main goal of the present study was to evaluate the reduction in genetic diversity of five A. angustifolia populations in southeastern Brazil, when compared with other populations from the south (the descendants of continuous forests).

\section{Methodology}

\section{Sampling}

In order to analyse a large part of the natural range of A. angustifolia, so as to compare genetic diversity between remnants of continuous forests in southern Brazil and isolated populations in the southeastern region, nine different populations located in the main area of distribution and in the northernmost limit of distribution of the species in Brazil, were sampled. Individuals from four populations in southern Brazil - São Francisco de Paula, in the state of Rio Grande do Sul (RS-1, RS-2 and RS-3) and Mangueirinha, in the state of Paraná (PR) - and individuals from five populations in southeastern Brazil - Itatiaia, Rio de Janeiro (RJ-1), Teresópolis, Rio de Janeiro (RJ-2, RJ-3 and RJ-4) and Liberdade, in the state of Minas Gerais (MG) - were sampled, comprising a total of 190 individuals (Table 1). In Teresópolis, where only small isolated patches of araucaria are to be found, and even so, normally located in grassland and pastures, all available individuals were sampled. Populations from the states of Rio Grande do Sul and Paraná consisted of fragments of continuous forests. On the other hand, populations from Minas Gerais and Rio de Janeiro were naturaly isolated by climatic and physical conditions. 


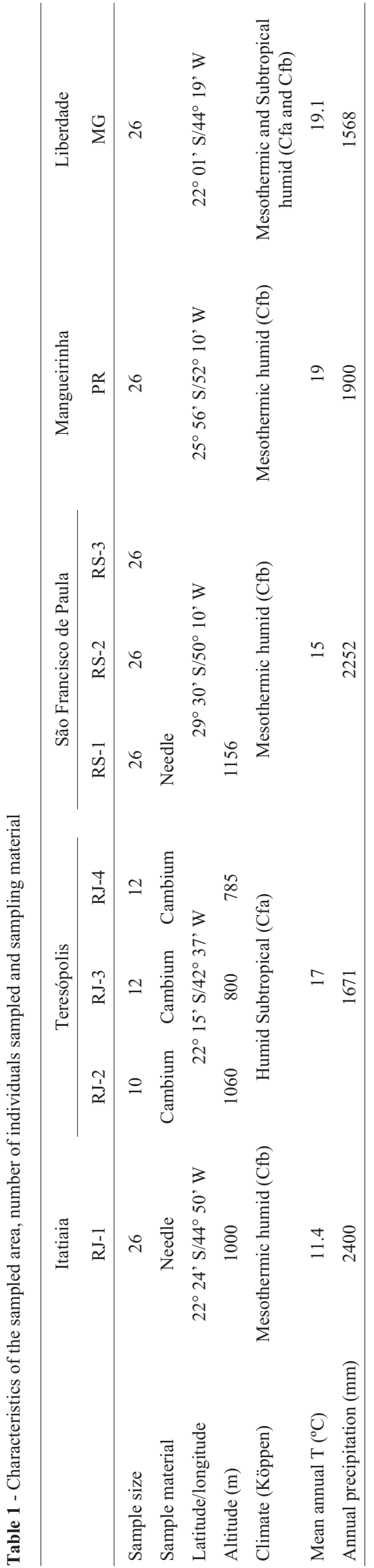

In each population, individuals were collected from 1 ha plots, the sampled trees being at the minimum $15 \mathrm{~cm}$ in diameter at breast height (DBH). Needle and cambium samples were stored during the collecting period (1-7 days) in silica gel and later kept in a freezer at $-80^{\circ} \mathrm{C}$.

\section{DNA extraction and AFLP analysis}

Needles and cambium were extracted according to the CTAB method (Doyle and Doyle, 1990) with modifications (Margis et al., 2002). AFLP analyses were perfomed based on Vos et al. (1995). Selective amplifications were done on the pre-amplified fragments by using six primerenzyme combinations (PECs): EcoRI-CA/MseI-GACC, EcoRI-CA/MseI-GCAC, EcoRI-CC/MseI-GACC, EcoRI$\mathrm{CG} / M s e I-G A C C, E c o R I-C G / M s e I-G C A C$ and EcoRI$\mathrm{CT} / M s e \mathrm{I}-\mathrm{GACC}$. The EcoRI primers were fluorescently labelled with either hexachlorofluorescein or 6-carboxyfluorescein (invitrogen $\odot$ ). A 3100 Genetic Analyzer ABI Prism 377 (Applied Biosystem $\AA$ ) automatic sequencer was used to obtain the electropherograms. Fluorescent AFLP patterns were scored with a Gene Mapper 3.5 (Applied Biosystem(C). The AFLP profiles of each individual were scored for band presence (1) or absence (0) to create binary matrices. Population allele frequency data were estimated from AFLPs loci, assuming Hardy-Weinberg equilibrium as described by Lynch and Milligan (1994).

\section{Data analysis}

\section{Genetic diversity}

The percentage of polymorphic loci estimates were calculated for each primer-enzyme combination (PEC) and for the six PECs together, based on $99 \%$ criteria, and using Population Genetic Analysis (TFPGA) software (Miller, 1997).

Genetic diversity indices were computed among individuals within the nine populations. First we considered the three populations from Teresópolis (RJ-2, RJ-3 and RJ-4) individually, and subsequently, due to the small sample size, we analyzed the three as one. Gene diversity for each population, total heterozygosity $(H t)$ and the number of polymorphic loci $(S)$ at $5 \%$ level were assessed using Arlequin (version 3.11, Excoffier et al., 2005). Gene diversity was estimated, assuming independent nuclear loci and Hardy-Weinberg equilibrium.

We also calculated an additional measure of population divergence, "the frequency-down-weighted marker values" (DW), as described by Schönswetter and Tribsch (2005). For each population, the number of occurrences of each AFLP marker therein was divided by the number of that particular marker in the total dataset. To even out unequal sample sizes, DWs were calculated among 26 individuals within seven populations (considering the three Teresópolis populations as one), and among 10 randomly chosen individuals within each of the nine original populations. 
Indirect measures of gene flow and relationships between populations

Genetic variation within and among groups and populations was tested by a non-hierarchical analysis of molecular variance (AMOVA, Excoffier et al., 1992) by using Arlequin (version 3.11, Excoffier et al., 2005) with a 5\% allowance for missing data. Total genetic variation was partitioned at three levels - among groups, among populations within groups and within populations. The significance of the differentiation was tested with 10.000 permutations, where $\mathrm{P}$ is the probability of observing a random value as large as or larger than the observed value and a confidence interval of $99.75 \%$. Correlation among the nine populations studied was assessed through clustering analysis based on Nei's unbiased genetic distances (Nei, 1978) and the UPGMA algorithm with the use of Tools for Population Genetic Analysis (TFPGA) software (Miller, 1997). Bootstrap was calculated after 10,000 replicates.

\section{Population genetic structure analysis}

Bayesian analysis with Structure Software (version 2.2, Pritchard et al., 2000) was used so as to investigate population structure. Our goal was to determine the most likely number of populations $(K)$. Analyses were carried out based on non-admixture and allele frequency correlated models, with 50.000 Markov Chain Monte Carlo (MCMC) steps and 10.000 burn-in periods. All the possible models for $A$. angustifolia from $K=2$ to $K=12$ were tried, and twelve replicates were run for each $K$. The most favourable $K$ was chosen according to that suggested by Evanno et al. (2005).

\section{Results}

\section{Genetic diversity}

The six primer-enzyme combinations used in this work yielded a total of 673 unambiguously scoreable fragments. The percentage of polymorphic loci for each primer-enzyme combination was higher in the southern populations and lower in populations RJ-2, RJ-3 and RJ-4. The highest percentage was found with PEC EcoRI-CG/MseI-
GCAC in PR (98.85\%) and the lowest with PEC EcoRI$\mathrm{CT} /$ MseI-GACC in RJ-2 (30.92\%). On following the same pattern, the percentage of polymorphic loci for all six primer-enzyme combinations, when considered together, yielded higher values in the southern populations and lower ones in southeastern populations RJ-2, RJ-3 and RJ-4 (Table 2). As can be seen in Table 3, population RS-1 presented the highest number of polymorphic loci (603), followed by that of PR (601). The MG population presented the lowest number of polymorphic loci (401). The estimates of gene diversity for all loci in each of the populations ranged from 0.16 to 0.27 (Table 3 ). The most diverse populations analysed were RS- 1 and PR (0.27). On the other hand, populations RJ-2, RJ-3, RJ-4 (considered individually), RJ (RJ-2, RJ-3 and RJ-4 considered as one, with 26 randomly chosen individuals), together with the MG population, presented the lowest estimates of gene diversity $(0.15-0.17)$. The total set of nine populations used in this analysis yielded a value for total heterozygozity of 0.27 . When 26 individual were considered per population, the "frequency-down-weighted marker values" (DW) ranged from $82.54(\mathrm{RS}-3)$ to $97.51\left(\mathrm{RJ}^{\#}\right)($ mean $91.9, \mathrm{SD}=5.37)$. On considering 10 randomly chosen individuals per population, DW ranged from 67.31 in population RS-2 to 84.00 in population $\mathrm{RJ}^{\#}$ (mean 75.7, $\mathrm{SD}=4,72$; Table 3 ).

\section{Indirect measures of gene flow and relationships between populations}

As expected, the genetic distance (Nei, 1978) was the highest between RS-1 and MG (mean $=0.076$ ), which are approximately $1034 \mathrm{~km}$ apart, and the lowest between populations RS-1 and RS-2 (mean =0.006) (Table 4). In spite of their geographical proximity, the outstanding point in this analysis was RJ-1 being more distant from the other four populations from southeastern Brazil (RJ-2, RJ-3, RJ4 and MG) than from the southern populations.

The UPGMA dendrogram generated from AFLP data (Figure 2) was supported by high bootstrap values, thereby implying the high reliability of the pattern found. The dendrogram seems to be divided into two highly supported

Table 2 - Percentage of polymorphic loci for each primer-enzyme combination (PEC).

\begin{tabular}{lccccccccc}
\hline & $\begin{array}{c}\text { RJ- } 1 \\
(\mathrm{n}=26)\end{array}$ & $\begin{array}{c}\mathrm{RJ}-2 \\
(\mathrm{n}=10)\end{array}$ & $\begin{array}{c}\mathrm{RJ}-3 \\
(\mathrm{n}=12)\end{array}$ & $\begin{array}{c}\text { RJ-4 } \\
(\mathrm{n}=12)\end{array}$ & $\begin{array}{c}\text { RS-1 } \\
(\mathrm{n}=26)\end{array}$ & $\begin{array}{c}\text { RS-2 } \\
(\mathrm{n}=26)\end{array}$ & $\begin{array}{c}\text { RS-3 } \\
(\mathrm{n}=26)\end{array}$ & $\begin{array}{c}\text { PR } \\
(\mathrm{n}=26)\end{array}$ & $\begin{array}{c}\text { MG } \\
(\mathrm{n}=26)\end{array}$ \\
\hline $\mathrm{CA} / \mathrm{GACC}$ & $78.78 \%$ & $40.15 \%$ & $56.81 \%$ & $49.24 \%$ & $89.39 \%$ & $81.81 \%$ & $71.96 \%$ & $78.03 \%$ & $40.90 \%$ \\
$\mathrm{CA} / \mathrm{GCAC}$ & $88.38 \%$ & $46.45 \%$ & $50.32 \%$ & $45.16 \%$ & $97.41 \%$ & $96.83 \%$ & $94.19 \%$ & $84.51 \%$ & $45.80 \%$ \\
$\mathrm{CC} / \mathrm{GACC}$ & $66.03 \%$ & $43.39 \%$ & $50.00 \%$ & $40.56 \%$ & $74.52 \%$ & $66.98 \%$ & $64.15 \%$ & $88.67 \%$ & $74.52 \%$ \\
$\mathrm{CG} / \mathrm{GACC}$ & $72.64 \%$ & $51.88 \%$ & $56.60 \%$ & $62.26 \%$ & $88.67 \%$ & $84.90 \%$ & $79.24 \%$ & $94.33 \%$ & $54.71 \%$ \\
$\mathrm{CG} / \mathrm{GCAC}$ & $65.51 \%$ & $51.72 \%$ & $49.42 \%$ & $50.57 \%$ & $93.10 \%$ & $89.65 \%$ & $96.55 \%$ & $98.85 \%$ & $75.86 \%$ \\
$\mathrm{CT} / \mathrm{GACC}$ & $65.97 \%$ & $30.92 \%$ & $40.20 \%$ & $36.08 \%$ & $84.53 \%$ & $72.16 \%$ & $89.79 \%$ & $89.69 \%$ & $73.19 \%$ \\
\hline Total & $73.69 \%$ & $46.21 \%$ & $53.34 \%$ & $47.84 \%$ & $89.59 \%$ & $83.50 \%$ & $79.34 \%$ & $89.30 \%$ & $59.58 \%$ \\
\hline
\end{tabular}

The percentages for each combination was calculated based on $99 \%$ criteria. 
Table 3 - Genetic diversity indexes for the nine Araucaria angustifolia populations analyzed.

\begin{tabular}{lcccccc}
\hline Populations & $\mathrm{N}$ & $\mathrm{S}$ & Frag $_{\text {priv. }}$ & $H$ & $\mathrm{DW}(\mathrm{n}=26)$ & $\mathrm{DW}(\mathrm{n}=10)$ \\
\hline RJ-1 & 26 & 496 & 7 & $0.20 \pm 0.18^{*}$ & 95.00 & 74.73 \\
RJ-2 & 10 & 311 & 0 & $0,16 \pm 0.19^{*}$ & - & 74.62 \\
RJ-3 & 12 & 359 & 0 & $0,17 \pm 0.19^{*}$ & - & 82.11 \\
RJ-4 & 12 & 322 & 0 & $0,15 \pm 0.19^{*}$ & - & 74.69 \\
RJ-2,3,4 & 26 & 435 & 6 & $0.16 \pm 0.08^{*}$ & 97.51 & 84.00 \\
RS-1 & 26 & 603 & 2 & $0.27 \pm 0.17^{*}$ & 87.42 & 71.00 \\
RS-2 & 26 & 562 & 2 & $0.26 \pm 0.18^{*}$ & 82.54 & 67.31 \\
RS-3 & 26 & 534 & 4 & $0.23 \pm 0.18^{*}$ & 90.39 & 74.69 \\
PR & 26 & 601 & 8 & $0.27 \pm 0.17^{*}$ & 94.87 & 77.68 \\
MG & 26 & 401 & 5 & $0.16 \pm 0.18^{*}$ & 95.56 & 77.16 \\
Mean & 21.1 & 465.6 & 3.4 & & 91.90 & 75.70 \\
Overall & 190 & 673 & & $0.27 \pm 0.26^{*}$ & & \\
\hline
\end{tabular}

$\mathrm{n}=$ sample size; $\mathrm{S}=$ number of polymorphic loci; Frag priv $=$ number of private fragments; $H=$ gene diversity; ${ }^{*}=$ standart deviation $(\mathrm{p}<0.05) ;{ }^{\#}=$ populations RJ-2, RJ-3 and RJ-4 considered as one.

Table 4 - Unbiased Nei genetic distances (Nei, 1978) among all the nine populations (below diagonal) and geographic distance between populations (km) (above diagonal).

\begin{tabular}{lcccccccrrr}
\hline & RJ-1 & RJ-2 & RJ-3 & RJ-4 & RS-1 & RS-2 & RS-3 & PR & MG \\
\hline RJ-1 & - & 204 & 204 & 204 & 978 & 978 & 978 & 859 & 56 \\
RJ-2 & 0.0580 & - & 2 & 2.5 & 1127 & 1127 & 1127 & 1052 & 175 \\
RJ-3 & 0.0474 & 0.0096 & - & 2.5 & 1126 & 1126 & 1126 & 1052 & 175 \\
RJ-4 & 0.0606 & 0.0101 & 0.0108 & - & 1126 & 1126 & 1126 & 1052 & 175 \\
RS-1 & 0.0291 & 0.0720 & 0.0566 & 0.0699 & - & 1 & 1 & 419 & 419 & 1034 \\
RS-2 & 0.0362 & 0.0796 & 0.0666 & 0.0754 & 0.0064 & - & 1 & -1034 \\
RS-3 & 0.0381 & 0.0741 & 0.0573 & 0.0681 & 0.0125 & 0.0092 & - & 419 & 1034 \\
PR & 0.0274 & 0.0446 & 0.0293 & 0.0461 & 0.0238 & 0.0312 & 0.0278 & - & 909 \\
MG & 0.0695 & 0.0359 & 0.0329 & 0.0330 & 0.0730 & 0.0767 & 0.0706 & 0.0403 & - \\
\hline
\end{tabular}

clusters, both of which consisting of the two regions analysed in this work - south (descendants of continuous forests) and southeast (relict populations). Nevertheless, RJ-1, which is located in the Brazilian southeast, clustered with populations from southern Brazil.

Genetic structure was assessed by using AMOVA. Four hypotheses were tested. In the first, all the nine populations were considered as being just one large group. In the second, two groups were taken into consideration, one consisting of the populations RS-1, RS-2, RS-3 and PR, and the other RJ-1, RJ-2, RJ-3, RJ-4 and MG. The third hypothesis also considered the same two groups, with the exception of $\mathrm{RJ}-1$, this being included in the southern group. In the fourth, there were five different populations, corresponding to the five genetic clusters identified from Bayesian analysis when using Structure Software (Pritchard et al., 2000). The first hypothesis tested yielded higher genetic variation among individuals within populations (81\%). However, on contemplating the hypothesis of two groups, a significant proportion of molecular variance was assigned to differences among groups (10\% and, 15\%) and among populations within groups $(12 \%$ and $9 \%)$. The last hypothesis was based on the results from Bayesian clustering. On identifying individuals belonging to each "genetic cluster", independent of their original location, five different populations were formed. The differences in total genetic variation partitioned into two levels (among populations and within populations) were tested According to the analysis, there was a higher variation within $(80 \%)$ and a lower one among populations (19\%) All values were highly significant $(\mathrm{p}<0.001)$ (Table 5).

\section{Population genetic structure analysis in $A$. angustifolia}

According to the approach suggested by Evanno et al. (2005), a population structure at only one level $(K=5)$ was indicated from Bayesian analysis The average non-admixture proportion for each population of A. angustifolia 


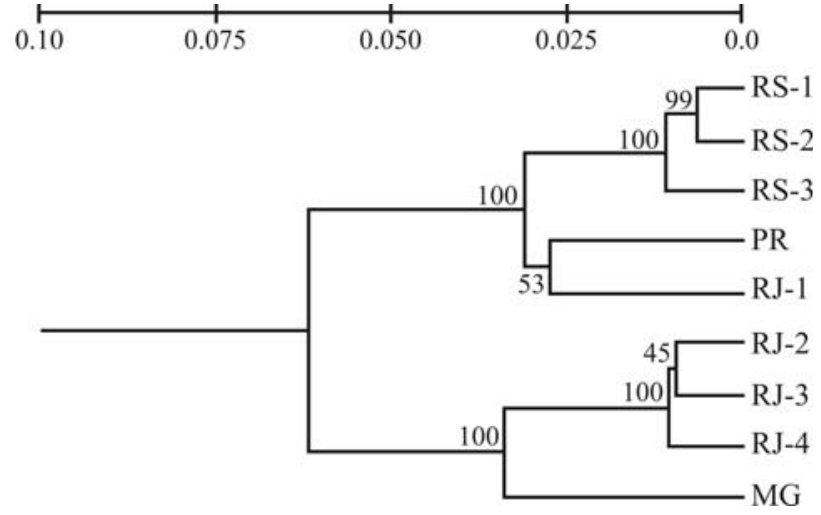

Figure 2 - UPGMA cluster analysis using Nei's unbiased genetic distance among nine $A$. angustifolia populations. Bootstrap values after 10.000 permutations are signalled at each node.

among the five different clusters found by means of this analysis appears in Table 6. Cluster 1 is mainly formed by individuals from the PR population. The second cluster is solely composed of individuals from populations RJ-2, RJ-3 and RJ-4. These three populations are geographically close to one another. The same pattern was observed with cluster 3, formed by populations RS-1, RS-2 and RS-3. Cluster 4 is mostly composed of the RJ-1 population, whereas cluster 5 is only formed by individuals from the MG population.

\section{Discussion}

\section{Genetic diversity and forest fragmentation}

Nowadays, habitat loss and fragmentation brought about by anthropogenic activities and environmental deterioration, with the consequential breaking up of large, continuous populations into small and isolated ones, have become the subject of major concern to conservation geneticists. Populations in fragmented habitats are considered more vulnerable to demographic, environmental and ge-
Table 6 - Average non-admixture proportion for each sampled population of Araucaria angustifolia among each of the five genetic clusters inferred from Bayesian analysis.

\begin{tabular}{lccccc}
\hline & \multicolumn{5}{c}{ Clusters } \\
\cline { 2 - 6 } Populations & 1 & 2 & 3 & 4 & 5 \\
\hline RJ-1 & 0.077 & 0.000 & 0.000 & 0.923 & 0.000 \\
RJ-2 & 0.200 & 0.800 & 0.000 & 0.000 & 0.000 \\
RJ-3 & 0.268 & 0.566 & 0.000 & 0.167 & 0.000 \\
RJ-4 & 0.167 & 0.833 & 0.000 & 0.000 & 0.000 \\
RS-1 & 0.269 & 0.000 & 0.500 & 0.231 & 0.000 \\
RS-2 & 0.116 & 0.000 & 0.654 & 0.231 & 0.000 \\
RS-3 & 0.115 & 0.000 & 0.731 & 0.154 & 0.000 \\
PR & 0.755 & 0.000 & 0.000 & 0.245 & 0.000 \\
MG & 0.039 & 0.000 & 0.000 & 0.000 & 0.961 \\
\hline
\end{tabular}

netic stochasticity, thereby facing a higher risk of local extinction (Boyce, 1992; Tilman et al., 1994, Lande, 1999). In this work, nine natural populations of $A$. angustifolia were investigated in order to define to what extent forest fragmentation and natural isolation can interfere in genetic diversity. As a result, accumulated data indicate higher genetic diversity in remnant populations of $A$. angustifolia in continuous forests in southern Brazil than in, isolated, relict populations in the southeast (Tables 2 and 3). Previous studies with the species also indicated higher diversity levels in continuous forest populations compared to fragmented populations in the south itself (Auler et al., 2002; Medri et al., 2003; Stefenon et al., 2007). The decrease in genetic diversity may occur due to a prolonged period following habitat isolation, or at short-term with the present habitat fragmentation (McDonald and Hamrick, 1996). Nevertheless, A. angustifolia populations from southern and southeastern Brazil underwent a similar level of exploitation during the last century. Therefore, recent deforesta-

Table 5 - Analysis of molecular variance (AMOVA) for four non-hierarchical models.

\begin{tabular}{llrrc}
\hline Hypothesis & Source of variation & d.f. & Variance components & Variation \\
\hline I & Among populations & 8 & 17.58924 & 19.01 \\
& Within populations & 181 & 74.91766 & 80.99 \\
\hline II & Among groups (S x SE) & 1 & 10.38166 & 10.70 \\
& Among populations within groups & 7 & 11.72282 & 12.08 \\
& Within populations & 181 & 74.91766 & 77.22 \\
\hline III & Among groups (S plus RJ-1 x SE) & 1 & 15.95329 & 15.86 \\
& Among populations within groups & 7 & 9.72750 & 9.67 \\
& Within populations & 181 & 74.91766 & 74.47 \\
\hline IV & Among "genetic clusters" & 4 & 18.44308 & 19.53 \\
& Within "genetic clusters" & & 75.99819 & 80.47 \\
\hline
\end{tabular}

After 10000 replicates $\mathrm{p}<0.001$, confidence interval: $99,75 \%$. 
tion could not be the main cause of the lower levels of genetic diversity in southeastern populations.

Nowadays, araucaria populations in southeastern Brazil are to be found as small isolated patches, normally restricted to higher altitudes on mountaintops (Mattos, 1994; Carvalho, 2003), thereby making gene flow difficult among populations. Pollen dispersal distance and the finescale genetic structure of $A$. angustifolia were analyzed by Bittencourt and Sebbenn (2008). Within the studied area, $A$. angustifolia manifested a spatial genetic structure at distances up to $75 \mathrm{~m}$. Based on paternity analysis, the calculated average pollination distance was $102 \mathrm{~m}$, and the effective number of pollen donors was 6.4 males, corresponding to an effective pollination neighborhood area of 2.1 ha. The authors concluded that these results imply long-distance pollen dispersion inside continuous Araucaria forests. Neertheless, the highest proportion occured at short-distances, thereby producing bi-parental and correlated mating as well as reducing variance effective size (Bittencourt and Sebbenn, 2008).

Taking into consideration the characteristics of species, populations and palynological records since the last glacial period, our results indicate that araucaria forests from Rio de Janeiro and Minas Gerais States have been isolated for thousands of years, with scarce mutual gene flow. Pollen records from Rio Grande do Sul (Behling et al. 2004), Santa Catarina (Behling, 1995) and Paraná (Behling 1997a), give evidence that $A$. angustifolia persisted in highland valleys during the late Pleistocene. The first wide expansion of $A$. angustifolia to the highlands in these studied regions may have occurred around 1.000 to $1.500 \mathrm{C}^{14} \mathrm{yr}$ $\mathrm{BP}$, when climatic conditions became more humid, with the absence of a marked dry season. Pollen records from Morro de Itapeva (São Paulo State, Southeastern Brazil) indicate warmer but still dry weather until around $2600 \mathrm{C}^{14} \mathrm{yr} \mathrm{BP}$. Under these conditions, A. angustifolia possibly survived in humid refugia. This dry period was followed by a more appropriate climate, suitable for the expansion of $A$. angustifolia to the highlands (Behling, 1997b). Nevertheless, the expansion of $A$. angustifolia to the southeastern highlands was probably less intense than in southern Brazil, possibly since the southeastern region had gone through relatively dry periods that delayed a recovery in population size (Behling, 2002). Therefore, in southern Brazil genetic signatures of population size reduction were lost, whereas these signatures persisted in southeastern populations (Stefenon et al., 2008a). Our estimates of genetic diversity indexes and DW values give support to this idea. As can be seen in table 3, populations in southeastern Brazil presented the highest DW levels. The value of DW is expected to be high in long-term isolated populations where rare markers should accumulate due to mutations (Schönswetter and Tribsch, 2005). Thus, our results indicate long-standing isolation and rare gene flow between southern and southeastern regions and among southeastern populations them- selves. In addition, it is possible that southeastern populations have gone through generations of the random effects of genetic drift. Bottleneck or founder effect events might also have led to a drop in population gene diversity. A previous study with araucaria populations from south and southeast Brazil described signatures of bottlenecks in all the southeastern populations analyzed, but in only three out of the 13 southern populations (Stefenon et al., 2008a). Therefore, it is possible to assume that the event may have occurred within the five southeastern populations of this research, although still further study is necessary to confirm this. Bottleneck effects could be intensified as a result of anthropogenic activities such as selective logging. Selective logging is probably another cause of the reduction in population size, thereby leading to a loss of rare alleles, a decrease in heterozigosity and increased populationinbreeding in araucaria forests. Nonetheless, even after the drastic exploitation in the last century, south Brazilian $A$. angustifolia populations still preserve their genetic diversity (Table 3). This is possibly due to forest fragmentation being recent and $A$. angustifolia a long-lived species that can live for 500 years. Due to the species high quality timber (Carvalho, 2003) and the importance of araucaria seeds as a source of nutrients for several human populations (Reitz et al., 1988), the transport of its seeds by natives or other more recent human populations cannot be ignored. Thus, present-day $A$. angustifolia distribution and genetic features may have been influenced by human interference. However, the observed reduction in genetic diversity in southeastern populations and the genetic differentiation between southern and southeastern populations are probably due, in the first place, to bottleneck events since the last glacial period, followed by a genetic drift, rather than to human exploitation (Lowe et al., 2004; Frankham et al. 2005).

\section{Relationships between populations}

Hamrick et al. (1992) pointed out the important role that a species geographical distribution and evolutionary history can play in determining the manner in which genetic diversity is distributed. The genetic distances in populations revealed an expected differentiation among southern and southeastern populations, with the exception of RJ-1 (Table 4, Figure 2). This high differentiation among southern and southeastern araucaria populations was also verified with the use of isoenzymic loci (Sousa et al., 2004) and microsatellite loci (Stefenon et al., 2007). In general, our results show that genetic distances among southern populations (RS-1, RS-2, RS-3 and PR) are lower than among southeastern populations (RJ-1, RJ-2, RJ-3, RJ-4 and $\mathrm{MG}$ ). For instance, populations RS-1,2,3 and PR are about $419 \mathrm{~km}$ apart and their genetic distances vary from 0.0064 to 0.0312 . On the other hand, populations RJ-1,2,3 and 4 are approximately $204 \mathrm{~km}$ apart and their genetic distances vary from 0.0096 to 0.0606 (Table 4). 
Prior to recent human interference, populations from south Brazil formed part of a continuous forest, with an expected and considerable gene flow, this being mainly responsible for diminishing their genetic distance. As araucaria is a long-lived species, it is possible that we are still observing the conditions of populations before human influence. The expected differentiation among regions can be explained by the behavior of araucaria forests during the glacial and inter-glacial periods. According to palynological data, during colder and drier periods (from about 35,000 to $17,000{ }^{14} \mathrm{C}$ years before the present) it is supposed that araucaria forests were restricted to protected valleys and wetter coastal slopes, besides bordering rivers and forming gallery forests (Behling, 1997b; Ledru et al., 1998). However, with the advent of warmer climates, these forests retracted, remaining restricted to higher altitudes, with cooler temperatures and a regular rainfall. (Behling, 1995; Kershaw and McGlone, 1995; Ledru et al., 1996). Therefore, since the last glacial period (about 18,000 to 15,000 years before the present; Brewer et al., 2002), the southeastern araucaria populations have always formed small, normally isolated patches on mountaintops (Ledru et al., 1996; Behling, 1998), with rare mutual gene flow. Thus, we can possibly assume that these small populations have undergone two genetic outcomes, genetic drift and inbreeding. Genetic drift is responsible for decreasing variation within populations (loss of alleles and heterozigosity) and increasing differentiation, whereas, inbreeding plays an important role by increasing homozygosity in small populations (Ellstrand and Elam, 1993). Both effects, added to the lack of gene flow due to natural isolation, possibly increased the genetic distance even among populations of southeastern Brazil.

The four hypotheses tested by AMOVA revealed that, despite fragmentation and natural isolation, the greater part of variation still resides within populations $(81 \%, 77 \%$, $74 \%$ and $80 \%$, Table 5). These results were expected for species with an $A$. angustifolia-like behaviour. According to Loveless and Hamrick (1984), anemochoric, allogamic and long-lived perennial species normally present greater molecular variance within the population itself than among populations. Furthermore, the values arrived at in this work are close to those found in other studies on araucaria (Mazza and Bittencourt, 2000; Stefenon et al., 2007) and other members of the Araucariaceae family (Bekessy et al., 2002; Pye and Gadek, 2004). The second and third hypotheses tested by AMOVA indicate that when the RJ-1 population was included in the southern group, the variation among groups increased. Therefore, we can suggest that this specific population is in fact more related to the southern populations and was responsible for diminishing the differences among groups. These results corroborate genetic distance (Table 4) and UPGMA dendrogram findings (Figure 2). When the fourth hypothesis was tested (five "genetic clusters" were considered based on Bayesian anal- ysis clustering), we also noticed the highest variation within clusters $(80 \%)$ and the lowest variation among clusters $(20 \%)$. Based on this result, it is possible to assume that we were dealing with five different genetic groups instead of just south-southeastern regional differentiation.

\section{Populations genetic structure analysis in $A$. angustifolia}

The Bayesian analysis provided insights regarding the genetic structure of $A$. angustifolia populations. First, it was possible to define an exclusive cluster for the MG population (cluster 5, Table 6) which is in agreement with its present condition. It is possible that, due to the population size and its complete isolation, it has been undergoing successive stochastic events, such as genetic drift, a reduction in genetic diversity and increasing genetic divergence among populations. In the second place, it disclosed one cluster for the three RS populations (cluster 3, Table 6) and another for the RJ-2, RJ-3 and RJ-4 (cluster 2, Table 6). Hence, we can possibly assume that in this study we were working with five genetic clusters instead of nine populations, as was predicted by their geographic locations. Third, this analysis resulted in one cluster essentially composed of individuals from population RJ-1 and with few individuals from the RS and PR populations (cluster 4, Table 6). This corroborates the genetic distance and UPGMA dendrogram findings. One genetic cluster (cluster 1, Table 6), basically composed of individuals from the PR population with some individuals from others, was also identified from Bayesian analysis. Thus, it is possible to suppose an ancient gene flow among these populations, mainly by means of pollen, the main factor responsible for long-range dispersal in $A$. angustifolia (Bittencourt and Sebbenn, 2007). It is also possible that at some time, a stepping-stone pollen-flow may have contributed to diminishing differentiation among populations (Stefenon et al., 2008b). However, selective logging of $A$. angustifolia forests in south Brazil, thereby reducing its area of natural occurrence, together with the probable isolation of southeastern populations on mountaintops, especially after the last glacial period, may have made gene-flow among populations difficult. According to Frankham et al., 2005, one indicator of the genetic impact of forest fragmentation and the consequent isolation is related to gene flow between populations. Forest fragmentation leads to two main events, the decrease in habitat-area and the appearance of small-sized isolated patches resulting in genetic drift (Freeland, 2005).

\section{Fragmentation and implication for conservation}

Genetic drift and inbreeding may influence small isolated plant populations by changing patterns of gene diversity and fitness. Both effects have implications for conservation. It is known that the loss of genetic variation may decrease the potential to persist in the face of biotic and abiotic environmental changes (Soulé, 1980; Simberloff, 
1988). It may also alter the ability of a population to endure short-term challenges, such as pathogens and herbivores (Huenneke, 1991). In this work, we learned that the genetic diversity of small, isolated populations of $A$. angustifolia in southeastern Brazil has been decreasing, mainly due to a series of events that have been corroding heterozygosity and increasing allele loss, which, in the near future could lead to extinction. Thus, conservation strategies for remnant populations of araucaria, particularly those in southeast Brazil, and that take into account the genetic distinctness of each population, are of extreme importance. Some populations of the species are already located in National Parks (Parque Nacional do Itatiaia, Parque Estadual dos Três Picos, among others) and thus are protected by Brazilian law, but there are still other relict populations left that need to be further studied and protected.

\section{Acknowledgments}

We would like to thank the financial support provided by the European Commission DGXII, International Cooperation with Developing Countries Programme, contract number ERBIC18CT970149; INCO-DEV project number ICA4-CT-2001-10101. Also the Pró-Mata Project (PUCRS) for the samples from Rio Grande do Sul. Souza, M.I.F., Salgueiro, F. and Carnavale-Bottino, M. received fellowships from CNPq (Brazilian National Council of Research). This work is part of the Master thesis of Souza, M.I.F. All the work described in this paper was undertaken according to Brazilian environmental legislation.

\section{References}

Auler NMF, Reis MS, Guerra MP and Nodari RO (2002) The genetics and conservation of Araucaria angustifolia: I. Genetic structure and diversity of natural populations by means of non-adaptive variation in the state of Santa Catarina, Brazil. Genet Mol Biol 25:329-338.

Behling H (1995) Investigations into the late Pleistocene and Holocene history of vegetation and climate in Santa Catarina (S. Brazil). Veget Hist Archaeobot 4:127-152.

Behling H (1997a) Late Quaternary vegetation, climate and fire history in the Araucaria forest and campos region from Serra Campos Gerais (Paraná), S Brazil. Rev Palaeobot Palynol 97:109-121.

Behling H (1997b) Late Quaternary vegetation, climate and fire history from the tropical mountain region of Morro do Itapeva, SE Brazil. Palaeogeogr Palaeoclimatol Palaeoecol 129:407-422.

Behling H (1998) Late Quaternary vegetational and climatic changes in Brazil. Rev Palaeobot Palynol 99:143-156.

Behling H (2002) South and Southeast Brazilian grasslands during Late Quaternary times: A synthesis. Palaeogeogr Palaeoclimatol Palaeoecol 177:19-27.

Behling H, Pillar V, Orlóci L and Bauermann SG (2004) Late Quaternary Araucaria forest, grassland (Campos), fire and climate dynamics, studied by high resolution pollen, charcoal and multivariate analysis of the Cambará do Sul core in
Southern Brazil. Palaeogeogr Palaeoclimatol Palaeoecol 203:277-297.

Bekessy SA, Allnutt TR, Premoli AC, Lara A, Ennos RA, Burgman MA, Cortes M and Newton AC (2002) Genetic variation in the vulnerable and endemic Monkey Puzzle tree, detected using RAPDs. Heredity 88:243-249.

Bittencourt JMV and Sebbenn AM (2007) Patterns of pollen and seed dispersal in a small, fragmented population of the wind-pollinated tree Araucaria angustifolia in southern Brazil. Heredity 99:580-591.

Bittencourt JMV and Sebbenn AM (2008) Pollen movement within a continuous forest of wind-pollinated Araucaria angustifolia, inferred from paternity and TWOGENER analysis. Conserv Genet 9:855-868.

Boyce MS (1992) Population viability analysis. Annu Rev Ecol Syst 23:481-506.

Bouzat JL (2001) The population genetic structure of the greater rhea (Rhea americana) in an agricultural landscape. Biol Conserv 99:277-284.

Brewer S, Cheddadi R, de Beaulieu JL and Reille M (2002) The spread of deciduous Quercus throughout Europe since the last glacial period. For Ecol Manag 156:27-48.

Busby JR (1991) BIOCLIM - A bioclimatic analysis and predictive system. In: Margules CR and Austin MP (eds) Nature Conservation: Cost Effective Biological Surveys and Data Analysis. CSIRO, Canberra, pp 64-68.

Carvalho PER (2003) Espécies Arbóreas Brasileiras. Volume 1. Embrapa Informação Tecnológica, Brasília, 1039 pp.

Doyle JJT and Doyle JL (1990) Isolation of plant DNA from fresh tissue. Focus 12:13-18.

Ellstrand NC and Elam DR (1993) Population genetics consequences of small population size: Implications for plant conservation. Annu Rev Ecol Syst 24:217-242.

Evanno G, Regnaut S and Goudet J (2005) Detecting the number of clusters of individuals using the software STRUCTURE: A simulation study. Mol Ecol 14:2611-2620.

Excoffier L, Smouse P and Quattro JM (1992) Analysis of molecular variance inferred from metric distances among DNA haplotypes: Application to human mitochondrial DNA restriction data. Genetics 131:479-491.

Excoffier L, Laval G and Schneider S (2005) Arlequin v. 3.0: An integrated software package for population genetics data analysis. Evol Bioinform Online 1:47-50.

Frankel OH and Soulé ME (1981) Conservation and Evolution. Cambridge University Press, 86 pp.

Frankham R, Ballou JD and Briscoe DA (2005) Introduction to Conservation Genetics. Cambridge University Press, Cambridge, $617 \mathrm{pp}$.

Freeland JR (2005) Molecular Ecology. Wiley, West Sussex, $400 \mathrm{pp}$.

Guerra MP, Silveira V, dos Reis MS and Schneider L (2002) Exploração, manejo e conservação de araucária (Araucária angustifolia [Bert]). In: Simões LL and Lino CF (eds) Sustentável Mata Atlântica: A Exploração de seus Recursos Florestais. Editora Senac, São Paulo, pp 85-101.

Hamrick JL, Godt MJW and Sherman-Broyles SL (1992) Factors influencing levels of genetic diversity in woody plant species. In: Adams WT, Strauss SH, Copes DL and Griffin AR (eds) Population Genetics of Forest Trees. Kluwer Academic Publ., Boston, pp 95-124. 
Hueck K (1972) As Florestas da América do Sul: Ecologia, Composição e Importância Econômica. Polígono, São Paulo, 466 pp.

Huenneke LF (1991) Ecological implications of variation in plant populations. In: Falk DA and Holsinger KE (eds) Genetics and Conservation of Rare Plants. Oxford Univ. Press, New York, pp 31-44.

IBAMA (1992) Lista Oficial das Espécies da Flora Brasileira Ameaçadas de Extinção. Diário Oficial. Portaria 006/92-N de 15 de janeiro de 1992 .

Kershaw AP and McGlone MS (1995) The quaternary history of the southern conifers. In: Enright NJ and Hill RS (eds) Ecology of the Southern Conifers. Melbourne University Press, Melbourne, pp 30-63.

Kershaw P and Wagstaff B (2001) The southern conifer family Araucariaceae: History, status, and value for paleoenvironmental reconstruction. Ann Rev of Ecol and System 32:397-414.

Koch I, Meireles LD, de Fraga CN and Sobral M (2007) As Gimnospermas ameaçadas de extinção no Estado do Espírito Santo. In: Simonelli M and de Fraga CN (eds) Espécies da Flora Ameaçadas de Extinção no Estado do Espírito Santo. Ipema, Vitória, pp 97-102.

Lande R (1999) Extinction risk from anthropogenic, ecological and genetic factors. In: Landweber LA and Dobson AP (eds) Genetics and Extinction of Species. Princeton University Press, New Jersey, pp 1-22.

Ledru MP, Braga PIS, Soubiés F, Fournier M, Martin L, Suguio K and Turcq B (1996) The last 50,000 years in the Neotropics (Southern Brazil): Evolution of vegetation and climate. Palaeogeogr Palaeoclimatol Palaeoecol 123:239-257.

Ledru MP, Salgado-Laboriau ML and Lorscheitter ML (1998) Vegetation dynamics in southern and central Brazil during the last 10,000 yrs BP. Rev Palaeobot Palynol 99:131-142.

Loveless MD and Hamrick JL (1984) Ecological determinants of genetic structure in plant populations. Annu Rev Ecol Syst 15:65-95.

Lowe L, Harris S and Ashton P (2004) Ecological Genetics: Design, Analysis, and Application. Blackwell Publishing, Oxford, $344 \mathrm{pp}$.

Lynch M and Milligan BG (1994) Analysis of population genetic-structure with RAPD markers. Mol Ecol 3:91-99.

McDonald DB and Hamrick JL (1996) Genetic variation in some plants of Florida scrub. Am J Bot 83:21-27.

Macedo AC (1993) Revegetação, Matas Ciliares e de Proteção Ambiental. Fundação Florestal, São Paulo, 27 pp.

Mantovani A, Morellato APC and Reis MS (2006) Internal genetic structure and outcrossing rate in a natural population of Araucaria angustifolia (Bert.) O. Kuntze. J Hered 97:466472.

Margis R, Felix D, Caldas JF, Salgueiro F, Araujo DSD, Breyne P, Van Montagu M, Oliveira D and Margis-Pinheiro M (2002) Genetic differentiation among three neighboring Brazilcherry (Eugenia uniflora L.) populations within the Brazilian Atlantic rain forest. Biodiv Conserv 11:149-163.

Marquesini NR (1995) Plantas usadas como medicinais pelos índios do Paraná e Santa Catarina, sul do Brasil: Guarani, kaingang, xokleng, ava-guarani, kraô e cayuá. Universidade Federal do Paraná, Curitiba, 290 pp.

Mattos JR (1994) O Pinheiro-Brasileiro. 2nd edition. Artes Gráficas Princesa LTDA, Lages, 226 pp.
Mazza MCM and Bittencourt JVM (2000) Extraction of DNA from plant tissue of Araucaria angustifolia (Araucariaceae). Bol Pesq Florestal 41:12-17.

Medri C, Ruas PM, Higa AR, Murakami M and Ruas CF (2003) Effects of forest management on the genetic diversity in a population of Araucaria angustifolia (bert.) O. Kuntze. Silvae Genet 52:5-6.

Menges ES (1991) Seed germination percentage increases with population size in a fragmented prairie species. Conserv Biol 5:158-164.

Miller MP (1997) Tools for Population Genetic Analyses (TFPGA) 1.3: A Windows Program for the Analysis of Allozyme and Molecular Population Genetic Data. Computer software distributed by author.

Nei M (1978) Estimation of average heterozygosity and genetic distance from a small number of individuals. Genetics 89:583-590.

Pritchard JK, Stephens M and Donnelly PJ (2000) Inference of population structure using multilocus genotype data. Genetics 155:945-959.

Pye MG and Gadek PA (2004) Genetic diversity, differentiation and conservation in Araucaria bidwillii (Araucariaceae), Australia's Bunya pine. Conserv Genet 5:619-629.

Reitz PR, Klein RM and Reis A (1988) Projeto Madeira do Rio Grande do Sul. Companhia Rio-Grandense de Artes Gráficas, Porto Alegre, $525 \mathrm{pp}$.

Rizzini CT (1976) Tratado de Fitogeografia do Brasil: Aspectos Ecológicos. Volume 1. Universidade de São Paulo, São Paulo, 327 pp.

Ruschi A (1950) Fitogeografia do Estado do Espírito Santo - I. Considerações gerais sobre a distribuição da flora no Estado do Espírito Santo. Boletim do Museu de Biologia Prof. Mello Leitão Série Botânica 1:1-353.

Schönswetter P and Tribsch A (2005) Vicariance and Dispersal in the Alpine Perennial Bupleurum stellatum L. (Apiaceae). Taxon 54:725-732.

Simberloff D (1988) The contribution of population and community biology to conservation science. Annu Rev Ecol Syst 19:473-511.

Shimizu JY, Jaeger P and Sopchaki SA (2000) Genetic variability in a remnant population of araucaria in the Iguaçu National Park, Brazil. Bol Pesq Florestais 41:18-36.

Soulé ME (1980) Thresholds for survival: Maintaining fitness and evolutionary potential. In: Soulé ME and Wilcox BA (eds) Conservation Biology: An Evolutionary-Ecological Perspective. Sinauer, Sunderland, pp 151-169.

Sousa VA, Robinson IP and Hattemer HH (2004) Variation and population structure at enzyme gene loci in Araucaria angustifolia (Bert) O. Ktze. Silvae Genet 53:12-19.

Stefenon VM, Gailing O and Finkeldey R (2007) Genetic structure of Araucaria angustifolia (Araucariaceae) populations in Brazil and the conservation of the species genetic resources. Plant Biol 9:516-525.

Stefenon VM, Behling H, Gailing O and Finkeldey R (2008a) Evidences of delayed size recovery in Araucaria angustifolia populations after post-glacial colonization of highlands in Southeastern Brazil. An Acad Brasil Ciênc 80:433-443.

Stefenon VM, Gailing O and Finkeldey R (2008b) The role of gene flow in shaping genetic structures of the subtropical conifer species Araucaria angustifolia. Plant Biol 10:356-364. 
Tilman D, May RM, Lehman CL and Nowak MA (1994) Habitat destruction and the extinction debt. Nature 371:65-66.

Vos P, Hogers R, Bleeker M, Reijans M, Van de Lee T, Hornes M, Frijters A, Pot J, Peleman J and Kuiper M (1995) AFLP: A new techique for DNA fingerprinting. Nucleic Acids Res 23:4407-4414.

Watts K, Humphrey JW, Griffiths M, Quine C and Ray D (2005). Evaluating Biodiversity in Fragmented Landscape: Principles. Forest Commission, Edinburgh, pp 1-8.

White GM, Boshier DH and Powell W (1999) Genetic variation within a fragmented population of Swietenia humilis Zucc. Mol Ecol 8:1899-1909.
Young A, Boyle T and Brown T (1996) The population genetic consequences of habitats fragmentation for plants. Trends Ecol Evol 11:413-418.

\section{Internet Resources}

IUCN, Red List of Threatened Species, http://www.iucnredlist.org/ (February 10, 2008).

Associate Editor: Márcio de Castro Silva Filho

License information: This is an open-access article distributed under the terms of the Creative Commons Attribution License, which permits unrestricted use, distribution, and reproduction in any medium, provided the original work is properly cited. 